Discourse and Communication for Sustainable Education, vol. 8, no. 1, pp. 90-101, 2017

\title{
Media and Environmental Non-Governmental Organizations (ENGOs) Roles in Environmental Sustainability Communication in Malaysia
}

\author{
Mohamad Saifudin Mohamad Saleh \\ School of Communication, Universiti Sains Malaysia
}

\begin{abstract}
Considering the massive environmental problems occurring in Malaysia, the media and the ENGOs are said to play pivotal roles in delivering environmental information to the mass society in order to increase their awareness, knowledge and practices towards the environment and sustainability. This study sought to shed the light on the type of roles can be played by the Malaysian media and the ENGOs in environmental sustainability communication. For the purpose of this study, 24 interviewees encompassing 13 media interviewees from two media organizations, namely Utusan Malaysia and The Star, as well as 11 ENGOs interviewees from two ENGOs organizations, WWF and MNS. The result of this study indicated that although both media and ENGOs seem to have different organizational backgrounds, particularly the media is a profitable organization whilst ENGOs are more non-profit oriented, when it comes to environmental communication, most of them agreed that they share quite similar roles particularly in informing and educating the public about environmental issues and in conducting research on environment and sustainability matters.
\end{abstract}

Keywords: Malaysia, environmental sustainability communication, media, ENGOs’ role.

\section{Introduction}

Nowadays, there are substantial amount of environmental problems such as landslide, haze, floods and others that continuously happened especially in developing countries such as Malaysia. For instance, water pollution has been said as one of the most serious environmental problem in Malaysia due to urbanization, human activities and natural causes (Afroz et al., 2014). Therefore, it is vital for social actors such as the media and the environmental non-governmental organizations (ENGOs) to take part in environmental sustainability communication, particularly in communicating environmental messages to the mass public. Environmental communication, it is hoped to increase the public awareness about environmental issues and to influence more environmental friendly and savvy attitudes (Willoughby \& Smith, 2016). Most importantly, communicating environmental information such as potential hazards or the environmental incident can minimize the risk of other environmental disasters (Sobnosky, 2001). 
Needless to say, although the environmental communication's development in the West has started in very early in the 1960s, especially through Rachel Carson's phenomenal book called 'Silent Spring' and Michael Harrington's spectacular book named 'The Other America' that fruitfully raised public awareness and debate on environment (Dreier, 2012) yet the environmental communication is quite a new field in Malaysia (Adnan \& Kamaliah, 2001). This might be due to the fact that environmental topics are less favorable by the nation compared to other topics such as politics and economy. Looking at the Malaysian media organization for example, until these days, there are no local media that has its own dedicated environmental desk that specifically focused on environmental news reporting (Nik Norma, 2007). Sadly, environmental news is usually placed together with other types of news, specifically under science and technology news desk. This is in contrast with Malaysian ENGOs such as the World Wide Fund for Nature (WWF) Malaysia, Sahabat Alam Malaysia (SAM), Malaysian Nature Society (MNS) and others that have given more attention on environmental issues compared to the media due to the fact that their organizations fully championed environment as the main issues of the organization while the media that need to focus on the variety of issues besides the environment.

Additionally, at this moment, there are very limited past Malaysian studies that covered on the topic of environmental sustainability communication particularly on the debate between the roles of media and ENGOs in environmental sustainability communication. It is even safe to say that there are no past studies that have compared the roles of both social actors in environmental sustainability communication within the Malaysian sphere. One of the related recent study that can be found on this topic is from Nur Nasliza \& Jamilah (2013) that studied how the mass media provides a great medium for the ENGOs in disseminating environmental and sustainability information and their communication relationship to each other. This study, therefore, sought to fill this essential gap by providing the current update regarding the roles of Malaysian media and ENGOs in environmental sustainability communication. There are two main questions that need to be answered in this study, first, what kind of roles played by the Malaysian media and ENGOs in environmental communication? And, second, does the Malaysian media and ENGOs that have different background of organizations (media for profit and ENGOs as non-profit) have different or similar roles in environmental sustainability communication? Next, the explanation of environmental communication will be provided.

\section{What is Evironmental Communication?}

As one might expect, environmental communication is a term that combined the words 'environment' or 'environmental' and 'communication'. Based on its definition, environment can be generally understood as the elements surrounding the human life, including soil, flora, fauna, air and so on. According to Morelli (2011), the word 'environmental' is often linked with the act of human beings towards the environment. In contrast, the word communication is defined as the process of exchanging and transmitting the information between one to another (Lunenbrug, 2010). Together, it is reasonable to define the environmental communication as the process of delivering information about environmental problems, for example, from the media to the public (Hansen, 2011). 
To be more specific, Cox (2013a) defined environmental communication as a form of symbolic action encompassing two types of functions, namely pragmatic and constitution function. The pragmatic function of environmental communication means that it can help to educate and persuade the recipients of environmental information to solve the environmental problems while the constitution function of environmental communication is more to constitute the power of environmental communication and represent the environmental problems for the recipients' understanding and awareness. Interestingly, both functions of environmental communication explained by Cox emphasized the power of language and picture in communicating environmental matters to the public. Cox (2006b) provided a great example of how ENGOs such as The Sierra Club used the headlines like "Now only you can save the Grand Canyon from being flooded... for profit" along with certain controversial pictures in their environmental campaigns to influence policy makers and the public about the impact of dam development. Next, the link between the sustainability and environmental communication will be explained.

\section{Sustainability and Environmental Communication}

Within the debate in the broad spectrum of environmental communication, many of us are still having trouble distinguishing between environmental and sustainability communication concept. Obviously, there are two different concepts, that are related to each other. Unlike the environmental communication that only focused on communicating the environmental issues, sustainability communication is associated with the concept of communicating sustainability messages (Newig et al., 2013; Salite, 2015; Salite, Drelinga, Iliško, Zarin,a, \& Oḷehnoviča, 2016), including issues on the environment, social justice and economy to the society (Villarino, \& Font, 2015; Mohamad Saifudin, \& Nik Norma, 2017; Iliško, 2007). This is similar to the confusion between the concept of environmental and sustainability education. Unlike environmental education that only focused on environmental education, sutainability education or also known as 'education for generation' (Aydin, 2016, p.101) taught on sustainability issues including the environment so that the students for example, are not only having a knowledge on sustainability, but more importantly having a sustainable lifestyle (Bell, 2016; Salīte, Drelinga, Iliško, Zarin,a, \& Oḷehnoviča, 2016).

As a whole, it is still intriguing to note that although these two types of communication have different issues to focus on, yet they actually have an almost similar goal which is to enhance society's awareness on issues on the environment. Most importantly, it is still interesting to note that some issues such as climate change and global warming are hard to distinguish whether it is the environment and sustainability issues, as sustainability itself also contained environmental element. Thus, the term environmental sustainability will be used for this study. Next, the description of the methodology of this study will be explained.

\section{Methodology}

For the purpose of this study, in-depth interviews were conducted with 24 interviewees from two selected mainstream media organizations and two ENGOs organizations in Malaysia. Out of the 24 interviewees, 13 of them were journalists and editors from Utusan Malaysia and The Star while 11 of them were ENGOs staffs from WWF 
and MNS. The reason for choosing the media interviewees from Utusan Malaysia and The Star due to the fact that these two newspapers have high daily publication circulation, where The Star has a circulation of 288,916 copies; Utusan Malaysia has a circulation of 178,211 copies per day (July to December, 2012) (Audit Bureau of Circulation Malaysia, 2012). Furthermore, both of these newspaper media organizations present the national language of Malaysia, Malay (Utusan Malaysia) and the second language of Malaysia, English (The Star). Similarly, the ENGOs interviewees were selected from WWF and MNS are due to the fact that both ENGOs organizations have been recognized as two most active ENGOs organizations in Malaysia in three main areas namely as research, education and conservation efforts beside of SAM (Rusli, \& Sheikh, 2005).

By using purposive sampling, only the media and ENGOs interviewees that have the experience in dealing with environmental communication such in writing environmental articles were selected for this study. The criteria for the interviewees was refined after the pilot interview which was conducted with two media and two ENGOs interviewees where it was found that is necessary to only interview the media and ENGOs interviewees that have had at least a year of working experience as they are more informative regarding environmental topics compared to the new staff. It is worth noting that besides purposive sampling, snowballing sampling method was also adopted where some of interviewees in this study were also recommended by their colleagues.

For the interview data analysis, qualitative data management software namely the Maxqda software was used in this study to analyze all the transcripts. All of the interview data were them analyzed and organized using Braun \& Clarke's (2006) thematic analysis to find a theme and sub-theme related to the roles of Malaysian media and ENGOs in environmental sustainability communication. Next, the findings of this study will be presented.

\section{Research Findings}

Firstly, the findings regarding the demographic profile of the interviewees of this study were explained. As shown in Table 1 below, 24 interviewees from four different organizations, encompassing two media organizations and two ENGOs organization participated in this study. All the interviewees were labeled using identification codes such EJ1, EN1 and so on for anonymity. Out of 24 interviewees, six of them were from The Star, seven from Utusan Malaysia, six from WWF and another five from MNS. It is safe to conclude that there are an equivalent number of interviewees who used English or Malay language during the interview. The interviewees' language preference was made by them in accordance with the language that they are comfortable with.

Additionally, it is worth to highlight that a majority of interviewees in this study are female (17 out of 24 interviewees) and at that time, a majority of them only have 1-5 years of working experiences (14 out of 24 interviewees). This could due the fact there are smaller numbers of media journalists and ENGOs managers that have acquired more work experiences, compared to the journalists and ENGOs officers. Interestingly, 21 from 24 interviewees of this study have acquired at least a bachelor degree and only one from Utusan Malaysia does not have a university degree. As expected, most of media interviewees graduated with degrees in communication and journalism background, while those from ENGOs came from various of backgrounds including science, environment, sustainability and other fields such as business and education. Next, the result of interview regarding the roles of Malaysian media and ENGOs in environmental sustainability communication will be displayed. 
Table 1

Profile of Interviewees

\begin{tabular}{|c|c|c|c|c|}
\hline & he $\operatorname{Star}(\mathrm{N})$ & Utusan Malaysia (N) & WWF (N) & MNS (N) \\
\hline Number of interviewees & 6 & 7 & 6 & 5 \\
\hline Identification codes & (EJ1-EJ6) & (EJ7-EJ13) & (EN1-EN6) & (EN7-EN11) \\
\hline \multicolumn{5}{|l|}{ Language } \\
\hline Malay & - & 7 & - & 3 \\
\hline English & 6 & - & 6 & 2 \\
\hline \multicolumn{5}{|l|}{ Gender } \\
\hline Male & 2 & 4 & - & 1 \\
\hline Female & 4 & 3 & 6 & 4 \\
\hline \multicolumn{5}{|l|}{ Working experience } \\
\hline $1-5$ years & 4 & 2 & 3 & 5 \\
\hline $6-10$ years & 1 & - & 3 & - \\
\hline $11-15$ years & - & 3 & - & - \\
\hline 16 years and above & 1 & 2 & - & - \\
\hline \multicolumn{5}{|l|}{ Education level } \\
\hline High school & - & 1 & - & - \\
\hline Bachelor degree & 6 & 6 & 5 & 4 \\
\hline Masters degree & - & - & 1 & 1 \\
\hline \multicolumn{5}{|l|}{ Background of study } \\
\hline Communication and journalism & m 4 & 3 & 1 & - \\
\hline Environment & - & 3 & - & 2 \\
\hline Science & 1 & - & - & 1 \\
\hline Sustainability & - & - & - & 1 \\
\hline Other & 1 & 1 & 5 & 1 \\
\hline
\end{tabular}

\section{Roles of Malaysian Media and ENGOs in Environmental Sustainability Communication}

In brief, the result of the interview indicated there are four major roles of Malaysian media and ENGOs in environmental sustainability communication, these roles are, (a) Reporting the environmental matters to the public (only for the media), (b) Conducting a research, (c) Informing, and (d) Educating about environment (for both media and ENGOs), as described below.

\section{Reporting Environmental Matters}

In general, the main role of the media particularly the journalist is to report environmental matters that happened in the country. Based on the interview, more than half of interviewees from the media (9 out of 13 interviewees) suggested that media plays a significant role in highlighting and reporting environmental issues like pollution, deforestation and destructions of hills (ID EJ1). Most importantly, through the media's environmental reporting, the mainstream public will be able to access the government's official environmental information (ID EJ2). Furthermore, through environmental reporting, the media actually serves immense roles in documenting certain pivotal environmental issues for future references as emphasized by one of the interviewees: 
I think I see the role of media is coordinating and crafting, and documenting pieces of history. It is not just about entertainment but it is about like about educating and documenting. There is another thing that other than education and awareness, is documenting stuffs. For example like with the monkey Malaria, maybe not everyone read it, but it is really interesting thing that happened in Malaysia which someone or news source should document (ID EJ6).

\section{Research Findings}

Majority of media and ENGOs interviewees expressed that conducting research on environmental issues is pivotal and is part of their essential duties in environmental sustainability communication. For the media, undertaking research is considered as one of their communal responsibilities (ID EJ2, EJ4, EJ5, EJ9, EJ10, EJ11), particularly in digging out and obtaining environmental information (ID EJ2). For investigators, there are countless numbers of ways to obtain environmental information as clarified by one of interviewees from The Star:

So, I guess that is kind of like first hand researching and we all have to do, of course, researching through Internet, through books, meeting and interviewing experts (ID EJ3).

For the ENGOs who work under the label of scientific-based organization, conducting research and data collection are some of their top priorities (ID EN1, EN2, EN4, EN5). Most of their research is in line with their championed issues (ID EN1, EN2, EN8), like issues on wildlife conservation as focused by WWF and preserving Malaysia's natural heritage, which is the focus of MNS. Nevertheless, by conducting researches, both ENGOs realized their prominent roles as stakeholders in undertaking conservation work. One of interviewees from WWF confirmed:

So, I think we are one important stakeholders conservation, Malaysia. We work towards providing solutions to the most pressing environmental issues and our priority is always our conservation projects (ID EN4).

Interestingly, as scientific-based organizations, both ENGOs have their own specific research teams that usually consist of research scientists (ID EN2), field and marine biologists (ID EN2) and conservation teams (ID EN7) who work and focus on conducting research on environment in the field. On the other hand, it is worth to note that one of the vital elements in delivering environmental information to the audience is the accuracy of the facts. In this regard, it is crucial for the ENGOs and the media to ensure every part of the environmental information is accurate to avoid the risk of misinformation. Thus, the ENGOs and media need to go down to the field and verify the obtained information with its (news) sources or through their own observation, before they can inform the public. One of the ENGOs clearly confirmed that:

I think they will look through into issues like, it sometimes it might not be something that is, we will find out whether it is true or not. The fact must be true. We cannot simply, they write something that is not true (ID EN8). 


\section{Informing Environmental Messages}

In brief, 8 out of the 11 of ENGOs interviewees and 5 out of 13 media interviewees mentioned the importance of informing the public about the environmental messages. Most of media interviewees described the importance of news article as the main medium to update environmental matters or events that occur locally or internationally.

To inform them on where these issues are happening and how it affects them (ID EJ3).

In contrast, ENGOs usually utilized their own magazines, newsletters and press releases to share environmental information with the public.

It is better to have a publication like magazine because through it we can share the information (ID EN11).

\section{Educating the Public About the Environment}

Despite informing or advocating environmental messages to the public, the Malaysian ENGOs and media are also speaking about their significant roles in educating the public about environmental issues. The majority of ENGOs (10 out of 11) and media (11 out of 13) interviewees shared similar views that their roles in environmental communication are not only to communicate green messages but also to provide environmental education. One of the ENGOs interviewee stated that:

So, I think NGOs play a very important role, by firstly educating the public. I think, I cannot comment on other NGOs, but from WWF's point of view, we have got the four pillars of our brand, it is we have got to be knowledgeable, optimistic, determine, and engaging (ID EN4).

The majority of the ENGOs and media interviewees contended that educating the public about environmental issues is aimed at raising environmental awareness on the importance of environmental protection and preservation among the Malaysian society, as stated by one of the media interviewees, who is the assistant editor from Utusan Malaysia:

I think one of the roles of media in communication is to arouse awareness among public through their write up (ID EJ11).

Another crucial element in environmental education is to deliver knowledge to the Malaysian society so that they will be able to understand and be aware of environmental issues that occur around them. From the result of the analysis, nearly half (6 out of 13) of the media interviewees spoke about the importance of delivering knowledge on the impacts of human activities towards Mother Nature. Meanwhile, only 2 out of 11 ENGOs interviewees discussed the same idea. According to one of the media interviewees:

What happens to the environment and what is happen to you if its caught. So we want to tell them that yes you can get in trouble, firstly with the authorities and then second you know, you are contributing to the haze that is going on around you (ID EJ3).

On the other hand, majority of ENGOs (5 out of 11) agreed on the significance of educating the public that it is important to protect the environment, as it is part of our livelihood. One of the examples is as follow: 
Because a lot of time it been keep saying the same thing and we say, 'save the forest, save the forest, save the forest', they are not going to, most people not going to understand, why should I save the forest? I am happy staying in my house, there is air conditioner... So they will not understand what is the link between me and the forest (ID EN3).

Additionally, the final aim of educating the society about environment is to encourage environmentally positive practices as a mean of environmental protection as explained by one of the media interviewees:

Tell them how they can play their role, how the public can play their role ensuring that they also contribute to the, to environmental cleanliness (ID EJ4).

\section{Discussion}

In brief, based on the explanations of the ENGOs and media interviewees, it is legitimate to also conclude that both social actors have shared quite similar roles in environmental sustainability communication, including the roles as an environmental researcher, informer and educator. It is illustrated that the difference in the business orientations of the media and ENGOs does not have a strong influence on the roles of media and ENGOs in environmental sustainability communication as both of them are focused to inform and educate the public on the environment. However, it is vital to note that only the media interviewees spoke about the roles in reporting environmental information, particularly environmental events. It is a plausible fact that the word 'reporting' and 'reporter' themselves have a strong connotations and are almost inseparable from the media. In other words, it is the media's general duty to report on any environmental issues that occur locally or internationally via several mediums like news article, feature, investigative reporting and so on, and obviously the ENGOs do not have to do any environmental news reporting. The environmental information reported by the media can influence public's knowledge and attitude towards environment (Keinonen et al., 2014).

Furthermore, it is also vital to note that both the Malaysian ENGOs and media in this study agreed that they have played a pivotal role in conducting field researches or investigation in order to ensure the accuracy of environmental information before writing the environmental stories and most importantly, to get an actual experience on the issue so that they can communicate it better to the public. Strikingly, the 'accuracy', 'truth', 'objectivity', 'honesty' and 'importance' of information are always their top priority as they are part of journalism ethics that are embedded in professional codes for the media (Hafez, 2002; Motlagh et. al, 2013). Thus, it is glaringly imperative for the journalists to verify the accuracy of the information that they received from the sources by experiencing it first hand to avoid the risk of misinformation. Past researchers, like Aram (2012) also emphasized the importance of site researches for environmental journalists. According to Aram, the environmental journalists are required to visit the site and accomplish a comprehensive research in order to get a grasp on complex environmental issues, listen to, people who were affected there and after that, report the stories in newspapers.

Contrary to the media, ENGOs working under so-called scientific organization, constantly put researches and conservations as their top priority. Both WWF and MNS have specific research teams who are responsible in conducting researches and conserv- 
ations in the field and most importantly, the research output will be shared as a report to the public via their newsletters, magazines, press releases and etcetera. It is safe to say that the WWF and MNS have conducted various researches and conversation projects. On top of that, WWF, for example, has conducted a Malayan tiger conservation project, where a research team actively monitors the land-use changes in tiger habitats in Malaysia. Previous researches like Rusli \& Lee (1999) also noted that WWF and MNS were two scientific organizations that were profoundly reliant on scientific data and research while Irini \& Norazlina (2012) noted that MNS as the oldest ENGOs in Malaysia have conducted massively successful conservation projects like halting the quarry at Batu Caves in 1980. In essence, such efforts are also observed in other developing Asian countries, where ENGOs have shown their active role in doing research and conservation. In Indonesia for instance, a Yogyakarta based NGO, APURA has been conducting a research on deforestation in the Wonosobo district, Central Java Province and shared the result with the local public and government agencies (Okamoto, 2001).

Apart from the roles in conducting research, it is discernible that the analysis of this study also unearthed that the ENGOs and media interviewees play significant roles, not only in informing the public, but also educating the society about environmental issues. Informing, as described by both media and ENGOs interviewees refers to the attempt to spread environmental messages to the ill-informed public. In the meantime, environmental education is more intensive, as it involves teaching the public about the environment function and how humans can manage the environment in sustainable ways (Chen, 2012). Consistent with the views of the media and ENGOs interviewees in this study, Aram (2012) explained that the fundamental goals of environmental education are to raise environmental awareness, deliver environmental knowledge and most importantly, instill an eco-centric attitude so that the society can be more environmentally sensitive. Wthout doubt, education is one of the vital tools in addressing the sustainability crisis (Raus, 2016). At the end of environmental education, the society is expected to change their behaviors (Hungerford \& Volk, 1990), and take their owns action in protecting the Mother Nature from any kinds of destruction, and live in sustainable ways.

The majority of media and ENGOs interviewees from this study greatly underscored the importance of educating the Malaysian society on these two key aspects, first, the knowledge on the negative impact of human actions towards the environment and the knowledge on the interconnection of environment towards their daily lives. For example, the society should be educated on the link between the increasing risks of certain diseases like Malaria to humans with ecological alterations like deforestation, so that they know humans are the cause and for them realize the importance of environment in their lives (Vittor et al., 2006). Without this knowledge and realization on the importance of environment to their everyday lives, the public would not care and they would not take any action (Singh, \& Serina, 2012). Next, the conclusion of this study will be provided.

\section{Conclusion}

By all accounts, it is safe to conclude that both Malaysian media and ENGOs have played significant roles in environmental sustainability communication. The finding of this study also discovered a new finding that the roles of Malaysian media and ENGOs in environmental sustainability communication are not limited to the cliché roles of just communicating or delivering environmental messages to the masses, but also includes 
other pivotal roles such as conducting field research and educating the public about the environment. Therefore, it will be great for the researchers in this area of study to understand that the scope of environmental sustainability communication should not too narrow and limited to only to communicating environmental messages. They also need to be linked with other crucial aspects such as environmental education and research and development. Besides that, this study shows that the environmental sustainability communication field, especially among the social actors likes the media and ENGOs have a great potential to be further studied and given more attention by the nation. In other words, it is the time for Malaysia to give serious attention to this area such as offering more courses in environmental communication in Malaysian university, as currently, only School of Communication in University Sains Malaysia offers Science and Environmental Journalism course for Master students. It also would be great if the Malaysian media organizations can provide environmental news reporting similar airtime as politic and economic news reporting to help improve the public's environmental awareness and knowledge. As a whole, I would recommend future researchers to study the roles of other stakeholders such as scientists, the government, institution of higher learning in environmental sustainability communication and compare their findings with the result of this study.

\section{Acknowledgements}

The researcher would like to cordially thank Universiti Sains Malaysia and the Malaysian Ministry of Education for his Ph.D scholarship at Leuphana University of Lüneburg, Germany. The researcher also wants to thank all his Ph.D supervisors (Prof. Dr. Harald Heinrichs, Prof. Dr. Daniel Fischer and Dr. Nik Norma Nik Hasan) and all the interviewees who prominently contributed in this study. Last but not least, the researcher also would like to thank the editors for their constructive comments.

\section{References}

Adnan, H., \& Kamaliah, S. (2001). Alam sekitar, kontroversi awam dan teori artikulasi: Satu analisis kontroversi projek hidro Bakun. [translate in English] Unpublished paper, Universiti Sains Malaysia.

Afroz, R., Masud, M. M., Akhtar, R., \& Jarita, D. (2014). Water pollution: Challenges and future direction for water resource management policies in Malaysia. Environment and Urbanization Asia, 5(1), 63-81. doi: https://doi.org/10.1177/09754253 14521544

Aram, A. (2012). Why do media academics keep off environmental reporting? Asia Pacific Media Educator, 22(2), 243-252. doi: https://doi.org/10.1177/1326365X 13498171

Audit Bureau of Circulation Malaysia (ABCM). (2012). Circulation figures newspapersPeninsular Malaysia, July 2012 To December 2012. Retrieved from: http://abcm.org. my/wp-content/reports/2012/ABC-Circulation-Figures-Pen-Mal-Geog-DistJul2012toDec2012.pdf

Aydin, S. (2016). Using excel in teacher education for sustainability. Journal of Teacher Education for Sustainability, 18(2), 89-104. doi: http://dx.doi.org/10.1515/jtes2016-0017 
Bell, D. V. J. (2016). Twenty first century education: Transformative education for sustainability and responsible citizenship. Journal of Teacher Education for Sustainability, 18(1), 48-56. doi: http://dx.doi.org/10.1515/jtes-2016-0004

Braun, V., \& Clarke, V. (2006). Using thematic analysis in psychology. Qualitative Research in Psychology, 3, 77-101. doi: http://dx.doi.org/10.1191/1478088706qp063oa

Chen, J. (2012). Contributions of environmental NGO to environmental education in China. IERI Procedia, 2, 901-906. doi: https://doi.org/10.1016/j.ieri.2012.06.189

Cox, R. (2013a). Environmental communication and the public sphere (3rd edition). Thousand Oaks, California: SAGE Publications.

Cox, R. (2006b). Environmental communication and the public sphere. Thousand Oaks, CA: Sage Publications.

Dreier, P. (2012). How Rachel Carson and Michael Harrington changed the world. Contexts, 11(2), 40-46. doi: https://doi.org/10.1177/1536504212446459

Hafez, K. (2002). Journalism ethics revisited: A comparison of ethics codes in Europe, North Africa, the Middle East, and Muslim Asia. Political Communication, 19(2), 225-250. doi: http://dx.doi.org/10.1080/10584600252907461

Hansen, A. (2011). Communication, media and environment: Towards reconnecting research on the production, content and social implications of environmental communication. The International Communication Gazette, 73(1-2), 7-25. doi: http://dx.doi.org/10.1177/1748048510386739

Hungerford, H. R., \& Volk, T. L. (1990). Changing learner behavior through environmental education. The Journal of Environmental Education, 21(3), 8-21. doi: http://dx.doi.org/10.1080/00958964.1990.10753743

Iliško, Dz. (2007). Teachers as agents of societal change. Journal of Teacher Education for Sustainability, 7, 14-27.

Irini, I., \& Norazlina, A. Z. (2012). The roles of international NGOs in the conservation of bio-diversity of wetlands. Procedia-Social and Behavioral Sciences, 42, 242247. doi: https://doi.org/10.1016/j.sbspro.2012.04.187

Keinonen, T., Yli-Panula, E., Svens, M., Vilkonis, R., Persson, C., \& Palmberg, I. (2014). Environmental issues in the media and students' perceptions in the three NordicBaltic countries. Journal of Teacher Education for Sustainability, 16(1), 32-53. doi: https://doi.org/ 10.2478/jtes-2014-0002

Lunenbrug, F. (2010). Communication: The process, barriers, and improving effectiveness. Schooling, 1(1), 1-11.

Mohamad Saifudin, M. S., \& Nik Norma, N. H. (2017). Do Malaysian journalists really understand what sustainability is? Journal of Sustainability Education, 13, 1-17.

Morelli, J. (2011). Environmental sustainability: A definition for environmental professionals. Journal of Environmental Sustainability, 1(2), 1-9. doi: https://doi.org/ 10.14448/jes.01.0002

Motlagh, N. E., Md Salleh, H. H., Jusang, B., \& Mohd. Nizam, O. (2013). Role of journalists' gender, work experience and education in ethical decision making. Asian Social Science, 9(9), 1-10. doi: http://dx.doi.org/10.5539/ass.v9n9p1

Nik Norma, N. H. (2007). The representation of environmental news: A comparative study of the Malaysian and New Zealand press (unpublished doctoral dissertation). University of Canterbury, New Zealand.

Newig, J., Schulz, D., Fischer, D., Hetze, K., Laws, N., Lüdecke, G., \& Rieckmann, M. (2013). Communication regarding sustainability: Conceptual perspectives and 
exploration of societal subsystems. Sustainability, 5, 2976-2990. doi: http://dx.doi. org/10.3390/su5072976

Nur Nasliza Arina, M. N., \& Jamilah, A. (2013). Effective environmental communication: A case study of environmental non-government organization (ENGO) in Malaysia. Journal of Social and Development Sciences, 4(6), 242-248.

Okamoto, S. (2001). The movement and activities of Environmental NGOs in Indonesia. Policy Trend Report, 13-23.

Raus, R. (2016). Modelling a learning journey towards teacher ecological self. Journal of Teacher Education for Sustainability, 18(2), 41-52. doi: https://doi.org/10.1515/ jtes-2016-0013

Rusli, M., \& Lee, K. C. S. (1999). Tactics of environmental NGOs in influencing public policy in Malaysia. Pertanika Journal of Social Sciences \& Humanities, 7(2), 71-77.

Rusli, M., \& Sheikh, A. B. A. (2005). Why Join an Environmental NGO? A case study of the Malaysian Nature Society. Pertanika Journal of Social Sciences \& Humanities, 13(1), 39-46.

Salìte, I., Drelinga, E., Iliško, Dz., Zariṇa, S., \& Oḷehnoviča, E. (2016). Sustainability from the transdisciplinary perspective: An action research strategy for continuing education course development. Journal of Teacher Education for Sustainability, 17 (2), 135-153.

Salīte, I. (2015). Searching for sustainability in teacher education and educational research: Experiences from the Baltic and Black Sea Circle Consortium for educational research. Discourse and Communication for Sustainable Education, 6, 21-29.

Singh, H. R., \& Serina, A. R. (2012). An approach for environmental education by Non-Governmental Organizations (NGOs) in biodiversity conservation. ProcediaSocial and Behavioral Sciences, 42, 144-152. doi: https://doi.org/10.1016/j.sbspro. 2012.04.175

Sobnosky, K. J. (2001). Effective communication in environmental management. Environmental Quality Management, 11(1), 47-56. doi: https://doi.org/10.1002/tqem.1204

Villarino, J., \& Font, X. (2015). Sustainability marketing myopia: The lack of persuasiveness in sustainability communication. Journal of Vacation Marketing, 21(4), 326-335. doi: https://doi.org/10.1177/1356766715589428

Vittor, A.Y., Gilman, R. H., Tielsch, J., Glass, G., Shields, T., Lozano, W.S., PinedoCancio, V., \& Patz, A. (2006). The effect of deforestation on the human-biting rate of Anopheles darlingi, the primary vector of Falciparum malaria in the Peruvian Amazon. Americal Journal Tropical Medicine and Hygiene, 74, 3-11.

Willoughby, J. F. \& Smith, H. S. (2016). Communication strategies and new media platforms: exploring the synergistic potential of health and environmental communication. Science Communication, 38(4), 535-545. doi: https://doi.org/10.1177/ 1075547016648151

Correspondence concerning this paper should be addressed to Mohamad Saifudin Mohamad Saleh, a lecturer in journalism department at School of Communication, Universiti Sains Malaysia. 